\title{
A catalogue of works attributed to the grammarian Herodian
}

\author{
Article \\ Published Version
}

Dickey, E. (2014) A catalogue of works attributed to the grammarian Herodian. Classical Philology, 109 (4). pp. 325345. ISSN 0009-837X doi: https://doi.org/10.1086/677859 Available at https://centaur.reading.ac.uk/38617/

It is advisable to refer to the publisher's version if you intend to cite from the work. See Guidance on citing.

To link to this article DOI: http://dx.doi.org/10.1086/677859

Publisher: University of Chicago Press

All outputs in CentAUR are protected by Intellectual Property Rights law, including copyright law. Copyright and IPR is retained by the creators or other copyright holders. Terms and conditions for use of this material are defined in the End User Agreement.

\section{www.reading.ac.uk/centaur}

\section{CentAUR}

Central Archive at the University of Reading

Reading's research outputs online 


\title{
A CATALOGUE OF WORKS ATTRIBUTED TO THE GRAMMARIAN HERODIAN
}

\author{
ELEANOR DICKEY
}

$\mathrm{T}$

HE WORKS ATTRIBUTED TO the grammarian Herodian have for centuries been one of the least understood topics of ancient scholarship. Battles may rage over Dionysius Thrax, but at least they are battles over a clearly defined question about a clearly identifiable work. Apollonius Dyscolus may be hard to read, but at least we have his works in something reasonably close to the form in which he wrote them. Herodian poses very different problems, as a huge corpus of works is attributed to him - fifty or more by most counts - and the vast majority of these are fragmentary, epitomized, heavily rewritten, or entirely spurious. ${ }^{1}$ To make matters worse, while almost all the works of the other major grammarians can be consulted in good modern editions, the works of Herodian are, with very few exceptions, available only in editions that not only are well over a century old but also were deeply problematic from the beginning.

Currently there is not even a complete and accurate list of the works attributed to Herodian and where they can be found. Four attempts at such lists are available: one implied by August Lentz's supposedly complete edition of Herodian's works, one in Pauly-Wissowa compiled by Hermann Schultz, one in the printed version of the Thesaurus Linguae Graecae Canon, and one in the online version of the TLG Canon. ${ }^{2}$ There are significant differences among the four lists, and none of them is complete or correct.

Major pitfalls await unwary scholars who venture to use such resources on Herodian as are available. Such readers might use the online $T L G$ to find and browse the works attributed to Herodian, and, if they do so, will find plenty of works that seem to be intact, cohesive compositions. Since the online $T L G$ provides only bare texts without apparatus or explanatory material, these readers have no way of knowing that much of the apparently intact material is in fact a nineteenth-century reconstruction of works that actually survive only in fragments and epitomes; most of the rest of it consists of spuria that the

\footnotetext{
I am grateful to Stephanie Roussou, George Xenis, Nigel Wilson, Ineke Sluiter, and above all Philomen Probert for help and encouragement with this project, and to Aikaterini Papazeti for allowing me to consult her unpublished dissertation.

1. Additionally, works not formally attributed to Herodian often contain Herodianic doctrine. Such works cannot be included here, but that does not mean that they are not important for reconstructing Herodian's views.

2. Lentz 1867-70; Schultz 1913; Berkowitz and Squitier 1990; and the online TLG at http://www.tlg.uci. edu/.
}

Classical Philology 109 (2014): 325-45

[@ 2014 by The University of Chicago. All rights reserved] 0009-837X/14/10904-0002\$10.00 
$T L G$ has failed to mark as such. These readers would have every reason to believe that words and phrases composed centuries after Herodian's death, in some cases even by the nineteenth-century editor, were the actual words of Herodian himself. Readers who use the actual editions rather than the $T L G$ are somewhat better off, but even the printed texts often fail to identify spuria and tend to blur the distinction between preserved material and reconstruction.

Warnings about the state of the texts of Herodian have, of course, frequently been uttered. They were proclaimed by Peter Egenolff more than a hundred years $\mathrm{ago}^{3}$ and more recently have been excellently reiterated and expanded by Andrew Dyck, ${ }^{4}$ who accompanied his warnings about the standard editions of Herodian with a detailed, work-by-work description of the most serious pitfalls and instructions as to how to avoid them by the use of other materials. Dyck's work is well known and has undoubtedly saved many readers from serious errors, but its existence has produced a problem of another kind. Because Dyck gives the impression of providing a comprehensive list of the problems and the works involved, readers now tend to believe that his article contains all the information they need in order to cope successfully with the works of Herodian and Pseudo-Herodian. ${ }^{5}$ But in fact Dyck's work discusses only fourteen of the more than fifty works in question: three-quarters of the works attributed to Herodian are not mentioned by Dyck at all.

This issue leaves people who need to use the works of Herodian in a very difficult position. If they run across a reference to a work in the Herodianic corpus, there is a good chance that that work will not be among those discussed by Dyck, and they will have no reliable way to find out what the work is, to what extent it is actually extant, whether it is genuine, or what published text of the work it is safe to use.

To remedy this situation I offer here what I believe to be the first correct list of the works attributed to Herodian. It is based on the following principles:

1) To help readers who encounter references to works of Herodian, all titles commonly found in scholarly literature as titles of works of Herodian are included, whether or not it is likely that Herodian actually wrote a separate work with that title. (When it is likely that there was no separate work with that title, this information is then given as well.) Titles are given in whatever language(s) they are normally found in scholarly literature; Greek titles are listed first, and the Latin ones follow.

2) Titles are listed in alphabetical order, rather than (as in other lists of Herodian's works) in the order of the works' appearance in Lentz's edition. The reason for this departure is to make it easier for readers to look up an individual title; when using other lists of Herodian's works one is obliged to look through the whole list in order to find out whether or not the work one is looking for appears. The disadvantage of alphabetical order is that some titles appear in more than one variant (e.g., with and without Пврí at the start); I

3. Cf. Egenolff 1900; 1902; and 1903.

4. Dyck 1993.

5. Cf. Dickey 2007, 76. 
have tried to remedy this situation by using cross-references from the variant forms.

3) Works generally agreed not to be by Herodian himself are marked with a marginal "Sp."; works of questionable authenticity are marked "Sp.?". Works not so marked should not always be assumed to be genuine, for some of the more obscure works have not received enough scholarly attention for their authorship to have been properly determined.

Although little was written on Herodian during the twentieth century, his works were a more popular topic in the nineteenth; as a result there is more scholarly literature than can be included in a piece of this nature. Much of it is discussed or at least mentioned by Schultz, whose work should be the first port of call after Dyck's for those seeking further information on the works listed here.

Some of the editions listed here are very difficult to get hold of. The author of this article has scans of most, though not all, of them and is happy to share these scans with readers on request, to the extent allowed by law.

\section{Catalogue}

\section{Greek Titles}

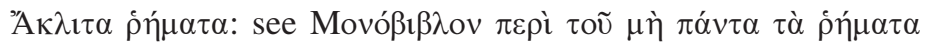

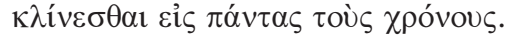

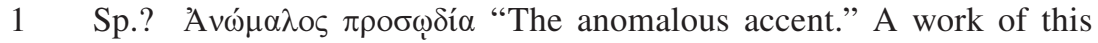
title is referred to, but its genuineness is suspect and only one fragment remains. ${ }^{6}$ This title is no. 48 in Schultz's list and does not appear in other lists.

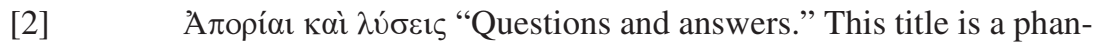
tom; no such work ever existed. The illusion seems to have arisen when Richard Reitzenstein referred to the extra portion of the

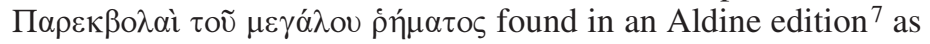
"die noch unbekannte erste Hälfte dieses Werkes" and discussed

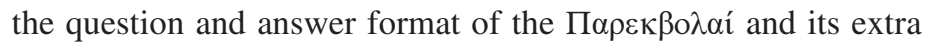
portion. ${ }^{8}$ Reitzenstein's discussion is not as clear as it could have been, and although someone who has seen the material in the Aldine edition can recognize what Reitzenstein is talking about and realize that he accidentally wrote "first half" when he meant "last few pages," a reader who had not seen the Aldine would not be able to work this out. Schultz admits that he had no access to the Aldine; ${ }^{9}$ as a result he misunderstood Reitzenstein to

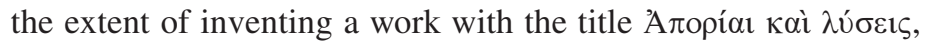

6. See Lentz 1867-70 in GG 3.2: xvii.

7. Manutius 1496; see Appendix to this article.

8. Reitzenstein 1897,364

9. Schultz 1913, 972. 


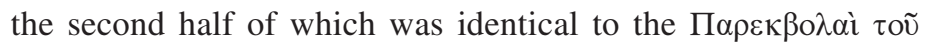

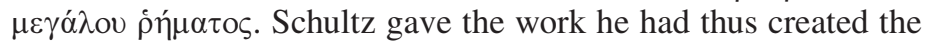
number 35, and the original compilers of the TLG Canon then

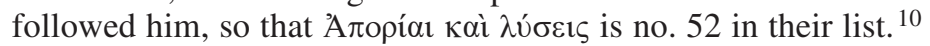
The error has been corrected in the online $T L G$, which makes no mention of this work.

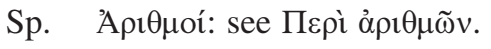

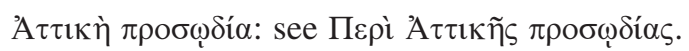

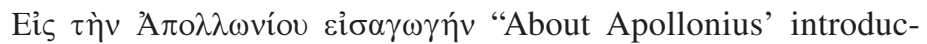
tion." One fragment survives attached to this title and is given by Lentz; ${ }^{11}$ the title was, however, probably just an alternative name for the Пвpi $\pi \alpha \theta \tilde{\omega} v$ (q.v.). The work is no. 32 in the lists of Schultz and the $T L G$.

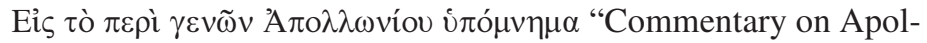
lonius [Dyscolus'] work on genders." We have only one fragment attached to this title, so it is unclear exactly what the work was about. The fragment is published by Lentz, ${ }^{12}$ and the work is no. 14 in both the TLG list and that of Schultz.

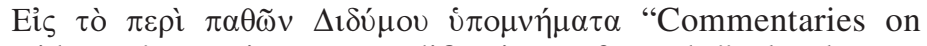
Didymus' [treatise] on modifications of words," also known

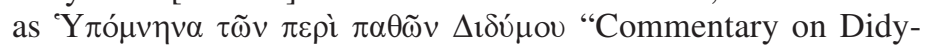

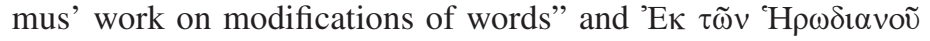
i $\pi \mathrm{o} \mu \nu \eta \mu \alpha ́ \tau \omega \nu \tau \tilde{\omega} \nu \pi \varepsilon \rho \grave{l} \pi \alpha \theta \tilde{\omega} v \Delta \mathrm{t} \delta \dot{\mu} \mu \mathrm{ov}$ "From Herodian's commentaries on Didymus' work on modifications of words." Three fragments are attached to this title; Lentz treated it as a separate work, but it is now generally agreed to be part of the Пвpi $\pi \alpha \theta \tilde{\omega} v$. In consequence this title is not listed on the $T L G$, and the relevant page of Lentz ${ }^{13}$ is found with the Пврі $\pi \alpha \theta \tilde{\omega} v$ on the database; Schultz, however, lists it as no. 8 and Dyck as no. 5. For further information see Dyck. ${ }^{14}$

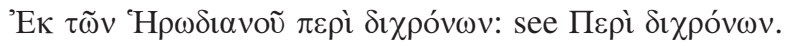

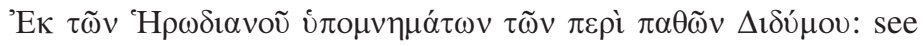

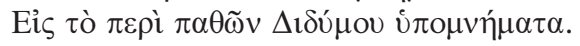
the attribution to Herodian is doubtful; see Lentz. ${ }^{15}$ This title is no. 40 in Schultz's list and does not appear in other lists.

10. Berkowitz and Squitier 1990, 197.

11. Lentz $1867-70$ in $G G 3.2$ : 907 ; cf. $G G$ 3.1: cxvii.

12. Lentz 1867-70 in $G G 3.2$ : 777; cf. $G G$ 3.1: cviii-cix.

13. Lentz 1867-70 in $G G 3.2$ : 389 ; cf. $G G$ 3.1: xcvi

14. Dyck 1993: 786-88.

15. Lentz $1867-70$ in $G G 3.1$ : xvi-xvii. 


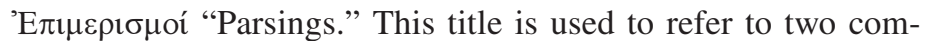
pletely different works. Schultz treats them both as no. 41 in his list; the TLG has only the second, as no. 36; and Dyck has only the first, as no. 14.

Sp.? The first work known as 'E $\pi \mu \mu \varepsilon \rho \sigma \mu o$ is a collection of fragments concerning etymology; Lentz thought that these were late creations and so could not have a connection with Herodian, but more recently Dyck has argued that the situation is more complicated. ${ }^{16}$ According to Dyck, the work is a composite production to such an extent that the question of authorship is meaningless: there may well be a core of material going back to Herodian or at least to his time, but it is no longer possible to separate this material from that derived from other sources. Lentz gives the majority of the fragments in his introduction, and Dyck adds some more; none of the fragments can be found on the TLG. ${ }^{17}$

Sp. The second work to which this title is applied is an intact piece of considerable dimensions, not by Herodian and probably significantly later than his time, concerning the spellings of vowel sounds that had originally been distinct but had subsequently become identical in Greek $(\alpha \mathrm{l} / \varepsilon, \varepsilon \mathrm{l} / \mathrm{l}$, etc.) and containing some discussion of accentuation. This work has been edited by Jean François Boissonade, with a supplement by Arthur Ludwich; ${ }^{18}$ Boissonade's edition but not Ludwich's supplement is on the $T L G$.

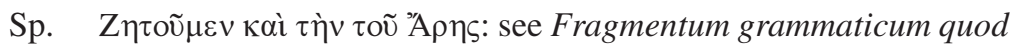

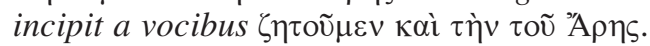

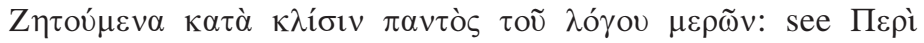

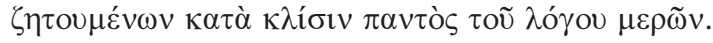

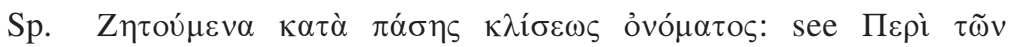

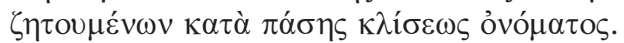

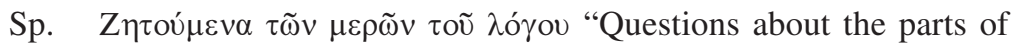
speech." This work, also known as Excerpta e Herodiano e cod. Paris. gr. 2552 "Excerpts from Herodian from cod. Paris. gr. 2552," is spurious and contains miscellaneous rules of grammar and usage. A text is given by Pierson and Koch, ${ }^{19}$ and the work is no. 46 in the TLG list and no. 42 in Schultz's list.

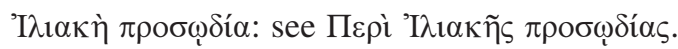

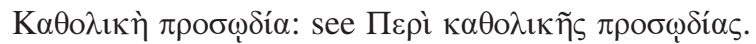

16. Dyck $1981 ; 1993,792-93 ; 1995,37-40$.

17. Lentz 1867-70 in GG 3.1: xvii-xxxiii; Dyck 1981, 231-32; 1993, 793.

18. Boissonade 1819; Ludwich 1905, 404bis-434.

19. Pierson and Koch 1830, 412-37. 


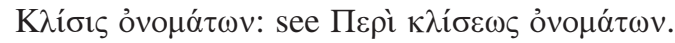

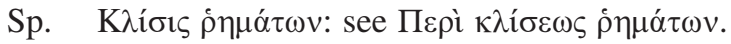

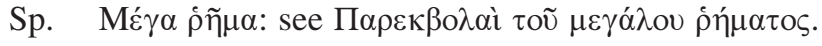

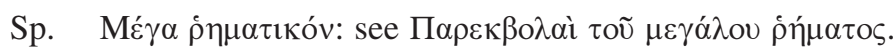

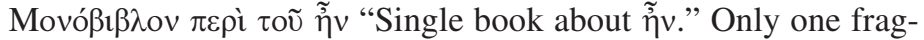
ment of this work remains, and it is not clear what aspects of the word $\tilde{\tilde{\eta}} v$ were discussed. The fragment can be found in Lentz's edition, ${ }^{20}$ and the work is no. 20 in the lists of both Schultz and the $T L G$.

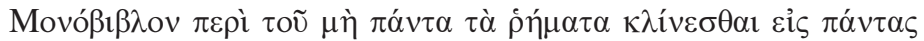

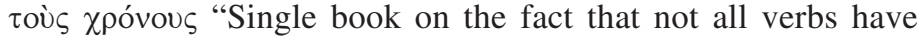

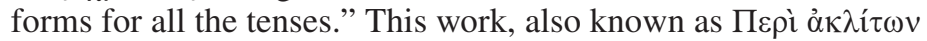

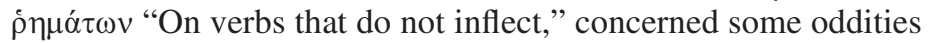
of conjugation; it now survives only in fragments. The fragments are published by Lentz, ${ }^{21}$ and the work is no. 18 in both the $T L G$ list and that of Schultz.

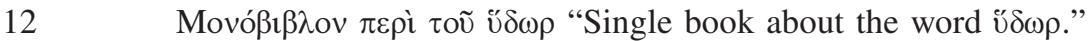
Only two fragments survive of this work, which presumably discussed the inflectional peculiarities of the word i $\delta \omega \rho$. The fragments can be found in Lentz's edition, ${ }^{22}$ and the work is no. 15 in both the $T L G$ list and that of Schultz.

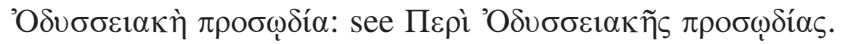

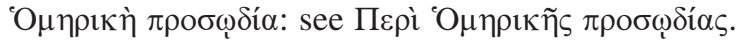

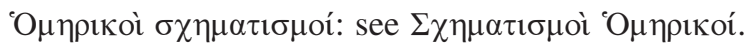

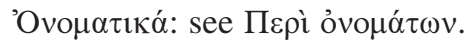

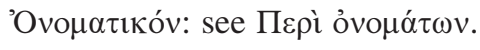

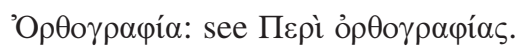

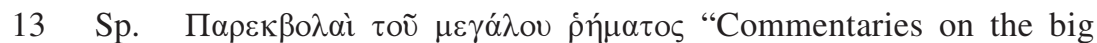
verb" (perhaps meaning the big treatise on the verb). This spurious work is a set of queries on oddities of conjugation, with explanations of strange forms. A text is given by J. La Roche, ${ }^{23}$ to which can now be added the fragment published below in the Appendix. The work is no. 49 in Schultz's list and appears in 49th

20. Lentz 1867-70 in $G G$ 3.2: 785-86; cf. $G G 3.1$ : cx.

21. Lentz 1867-70 in $G G$ 3.2: $779-84$ + corrigenda 1261-62; cf. GG 3.1: cx.

22. Lentz 1867-70 in $G G 3.2$ : 777 ; cf. $G G 3.1$ : cix

23. La Roche 1863. 
place in the list on the online $T L G$; the work number ${ }^{24}$ in the $T L G$ is 50, as in the printed $T L G$ list. ${ }^{25}$

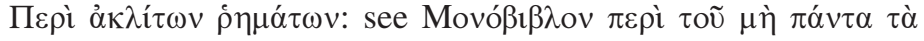

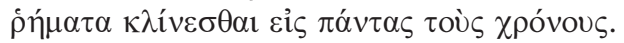

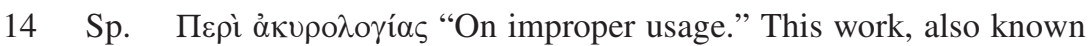
as De impropria dictione, is traditionally classified with the spuria and concerns the correct meanings of various words with warnings against using them in their incorrect (i.e., post-classical) senses. A text can be made by combining material given by August Nauck with that offered by G. Vitelli; ${ }^{26}$ neither of these sources is in the $T L G$, and the work does not appear in the $T L G$ list. It is no. 34 in Schultz's list and no. 11 in Dyck's.

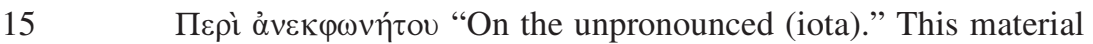
on spelling with iota subscript (a problem already in the Hellenistic period, when the long diphthongs now written with iota subscript ceased to be pronounced differently from long vowels that were not historically diphthongs) was probably part of the Пврі

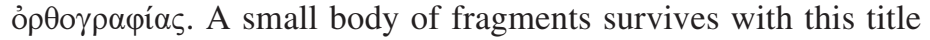
and is printed by Lentz. ${ }^{27}$ The work is not listed separately in the

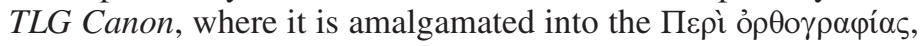
but is no. 11 in Schultz's list.

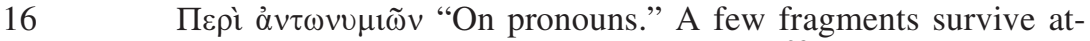
tached to this title and are given by Lentz. ${ }^{28}$ Hartmut Erbse has argued that they do not come from an independent work but must have been part of another larger one. ${ }^{29}$ The work is no. 23 in the lists of both Schultz and the TLG, and no. 8 in Dyck's list.

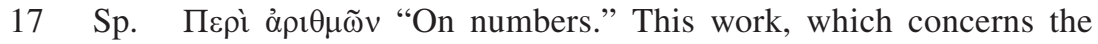
acrophonic numeral system used in classical Attic inscriptions, is traditionally classified with the Herodianic spuria. A text can be found in the appendix to the Thesaurus of Henricus Stephanus, also known as Henri Estienne, who accompanies it with a Latin translation and extension. ${ }^{30}$ The $T L G$ has part of the Greek text (the narrative portion, but not the table of numbers, which Stephanus indicates was present in his source), but not the translation or extension. The work is no. 42 in the TLG list and no. 36 in that of Schultz.

\footnotetext{
24. The TLG Canon lists fifty works of Herodian in an order determined by their serial numbers, which appear at the start of the entry for each work and represent the order in which they were digitized. The work

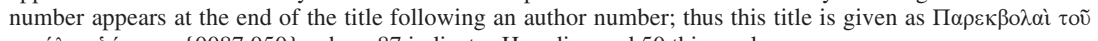
$\mu \varepsilon \gamma \alpha \dot{\lambda}$ ov $\dot{\rho} \eta \mu \alpha \tau o \zeta\{0087.050\}$, where 87 indicates Herodian and 50 this work.

25. Berkowitz and Squitier 1990.

26. Nauck 1867, 313-20; Vitelli 1889.

27. Lentz 1867-70 in $G G 3.2: 421-22$; cf. $G G 3.1$ : cv.

28. Lentz 1867-70 in $G G$ 3.2: 845-46; cf. $G G 3.1$ : cxiii.

29. Erbse 1960: $85-86$

30. Stephanus $1865,345-54$ (appendix I).
} 


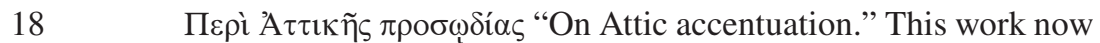
survives only in a few fragments, some of which are given by Lentz and another only by Herbert Hunger. ${ }^{31}$ The work is no. 6 in the TLG list, no. 5 in Schultz's list, and no. 4 in Dyck's.

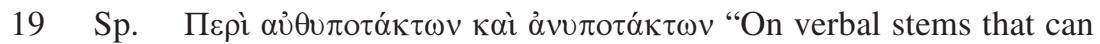
or cannot be used as the basis for subjunctives." This work, traditionally classified with the spuria, concerns various ways in which subjunctives (usually aorist subjunctives) can be related to the rest of the verbal paradigm. It seems to be a version of the doctrine also found in the Pseudo-Herodianic 'E $\pi \mu \varepsilon \rho ı \sigma \mu o$ í. ${ }^{32} \mathrm{~A}$ text is given by Bekker, ${ }^{33}$ and the work is no. 43 in the $T L G$ list and no. 37 in that of Schultz.

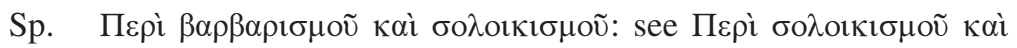
$\beta \alpha \rho \beta \alpha \rho \iota \sigma \mu о \tilde{\text {. }}$

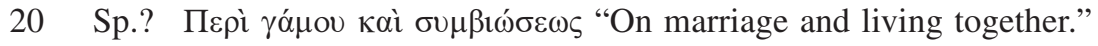
Only one fragment of this work survives, so it is difficult to know what it was about, and the apparently nongrammatical orientation is uncharacteristic of Herodian. The fragment is given by Lentz, ${ }^{34}$ and the work is no. 29 in the lists of Schultz and the $T L G$.

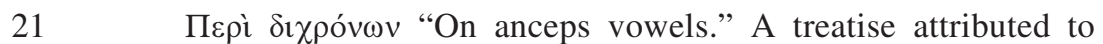
Herodian is preserved under this title, but the material in it may

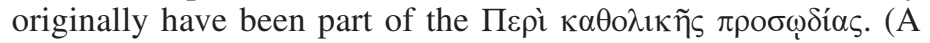

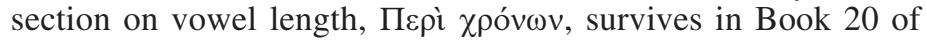

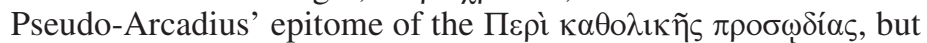
the epitome of Book 20 is probably not part of Pseudo-Arcadius' work, for it is an addition in one late manuscript. Nevertheless, the work's table of contents indicates that Book 20 did originally contain a discussion of vowel length, and it is possible that the

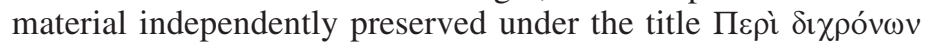
is a set of extracts from that original Book 20.) Largely the same excerpts are found, together with other material, as part of the Regulae de prosodia in an edition by Gottfried Hermann; ${ }^{35} \mathrm{cf}$.

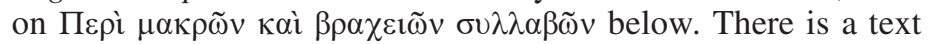
in Lentz's edition of Herodian. ${ }^{36}$ This work is no. 4 in the $T L G$ list and no. 3 in Schultz's list. See Dyck. ${ }^{37}$

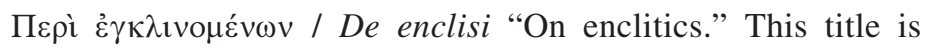
sometimes listed as belonging to a self-standing work, but the

31. Lentz 1867-70 in GG 3.2: 20-21; cf. GG 3.1: 1xxiii-lxxiv; Hunger 1967, 14-15.

32. Boissonade 1819, 277.8-280.9.

33. Bekker $1821,1086-88$

34. Lentz 1867-70 in $G G$ 3.2: 904; cf. $G G$ 3.1: cxvi.

35. Hermann $1801,432.21-449.11$.

36. Lentz 1867-70 in $G G$ 3.2: 7-20 + corrigenda 1240; cf. GG 3.1: 1xxii.

37. Dyck 1993, 783. 
piece to which it is attached was probably an appendix to the

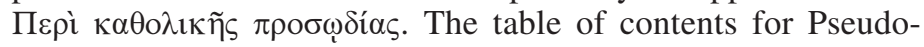

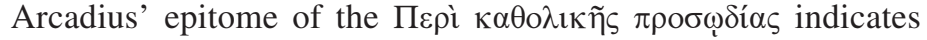
that there was a discussion of enclitics in an appendix (sometimes called Book 21), but this is lost. In Book 15 of Pseudo-Arcadius' epitome, however, there are two discussions ${ }^{38}$ of this subject, and it is thought that one or both discussions may contain material derived (whether more or less distantly) from the lost appendix. Some more material that might derive from the appendix can be found in other sources, some attributed to Herodian and some

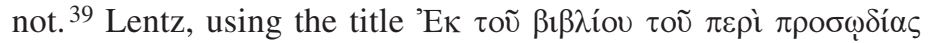
$\tau \tilde{\eta} \varsigma \kappa \alpha \tau \grave{\alpha} \sigma u ́ v \tau \alpha \xi_{1 v} \tau \tilde{\omega} \nu \lambda \varepsilon^{\prime} \xi_{\varepsilon \omega \nu}$ "From the book about prosody in connected writing," 40 has reconstructed a discussion from these and other sources, and the TLG gives Lentz's text with the title $\Pi \varepsilon \rho \grave{\varepsilon} \dot{\varepsilon} \gamma \kappa \lambda \mathrm{\imath} v \rho \mu \varepsilon \dot{\varepsilon} \omega \omega$ as if it were a self-standing work. This work is no. 2 in the TLG list; Schultz does not list it as a separate work.

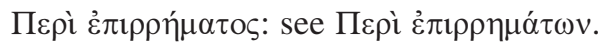

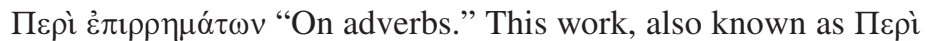

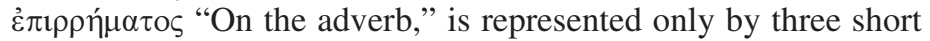
fragments, which are given by Lentz. ${ }^{41}$ The work is no. 24 in the lists of both Schultz and the TLG.

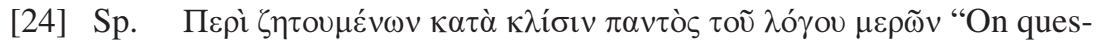
tions concerning the declension of the parts of all speech." This title is occasionally used as an overarching designation for Пєрì

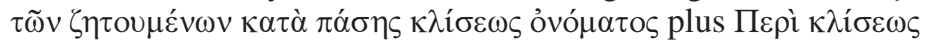
$\nmid \eta \alpha \dot{\tau} \tau \omega v$ (both probably spurious), qq.v.; it is effectively the same

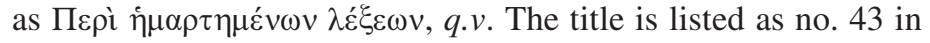
Schultz's list and does not appear in other lists.

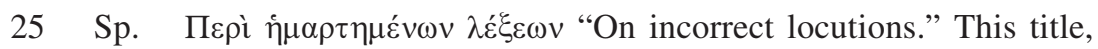
sometimes translated into Latin as De locutionum pravitatibus "On errors of speech," is sometimes used as an overarching des-

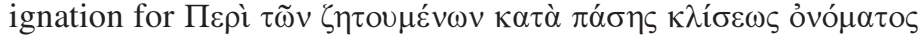

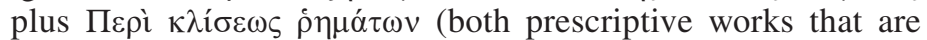

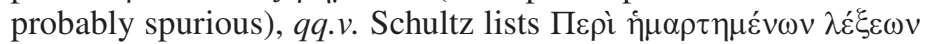
as a work distinct from those two, referring to a very old edition of Hermann, but the text given by Hermann ${ }^{42}$ is basically the same

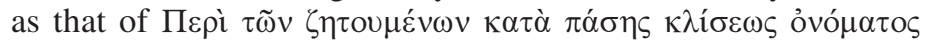

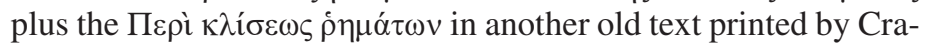
mer. ${ }^{43}$ Hermann's edition is based on one manuscript; Cramer's

38. These can be found in Schmidt 1860, 159-62 and 162-69.

39. This material is published by Bekker $1821,1142-58$.

40. Lentz 1867-70 in $G G 3.1: 551-64$ + corrigenda in $G G 3.2: 1240$.

41. Lentz $1867-70$ in $G G 3.2$ : 846; cf. $G G 3.1$ : cxiii.

42. Hermann 1801, 301-18.

43. Cramer 1836, 246-62. 
is based primarily on a different manuscript but also makes use of Hermann's edition and several other sources. ${ }^{44}$ The sources are helpfully discussed by Cohn. ${ }^{45} \mathrm{~A}$ small amount of additional material belonging to this work has subsequently been edited by Alphonse Dain. ${ }^{46}$ The title is no. 38 (Dain's material) + no. 47 (Cramer's material) in the TLG list, and no. 46 in Schultz's list.

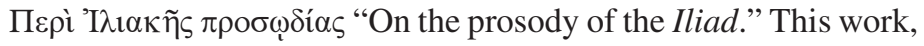
which consisted of observations on accentuation, aspiration (i.e., smooth and rough breathings), and vowel length in the Iliad, may have been an early work that preceded Herodian's main work on

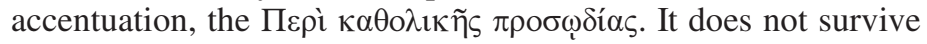
via direct transmission, but a large amount of material from it was incorporated into the scholia to the Iliad. It therefore survives in numerous fragments gathered from the scholia, though in most cases there is no explicit attribution to Herodian in the scholion. There is a text in Lentz's edition, ${ }^{47}$ but since he was using poor editions of the scholia it is better to consult Erbse's edition of the Iliad scholia, ${ }^{48}$ where the relevant scholia are marked "Hrd." in the margin. Both Lentz's edition and Erbse's can be found on the $T L G$, which thereby tends to give the impression that material in this work is attested twice. This work is no. 7 in the $T L G$ list, no. 6a in Schultz's, and no. 2 in Dyck's; for further information see Dyck. ${ }^{49}$

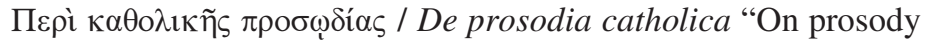
in general." This was Herodian's main work, probably written af-

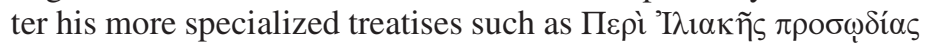

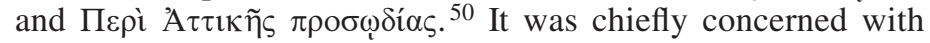
accentuation and now survives only in fragments and epitomes, from which Lentz has reconstructed the work. ${ }^{51}$ It is safer to use the surviving material itself than to use Lentz's reconstruction (particularly as some of the surviving material was unavailable to Lentz); this material is mainly to be found in an epitome attributed to Arcadius, an epitome attributed to John Philoponus, a palimpsest fragment, and a papyrus fragment. ${ }^{52}$ The Пврі

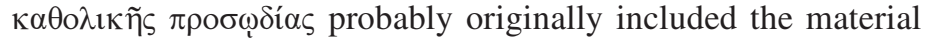

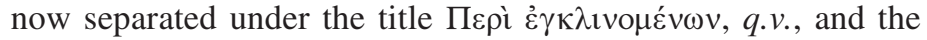

44. Cf. Cramer 1836, $246 \mathrm{n}$

45. Cohn 1888, 406-7.

46. Dain 1954, 73-74.

47. Lentz 1867-70 in $G G$ 3.2: $22-128$ + corrigenda 1240 ; cf. $G G$ 3.1: lxxiv-lxxxii.

48. Erbse 1969-88.

49. Dyck 1993, 783-86.

50. Cf. Dyck 1993, 774 n. 5; Hunger 1967, 14.

51. Lentz 1867-70 in GG 3.1: 1-547 + corrigenda in GG 3.2: 1233-40; cf. GG 3.1: xxxv-lxxi.

52. For Pseudo-Arcadius there is an inadequate edition by Schmidt (1860) and a new one in preparation by Stephanie Roussou; for Philoponus there is an inadequate edition by Dindorf (1825) and a new one about to appear (Xenis 2014); the palimpsest fragment has been edited by Hunger (1967) and the papyrus by Wouters (1979, 216-24). 


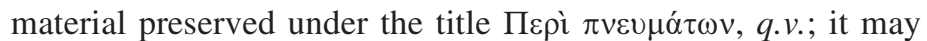
also have included the material preserved under the title Пврі

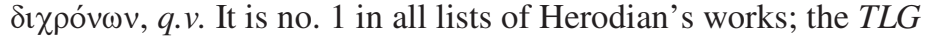
gives Lentz's text but also includes the Arcadius epitome as a separate work, thereby sometimes giving the erroneous impression that material in this work is attested in two separate places. ${ }^{53}$

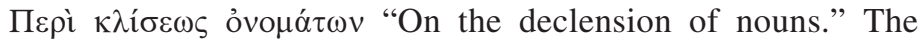
substantial body of fragments under this title, most of which come from Choeroboscus, was probably originally part of the

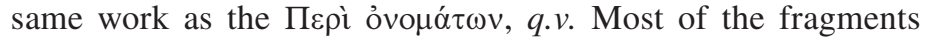
are published by Lentz, ${ }^{54}$ but as there is now a better edition of Choeroboscus (in $G G$ vol. 4) than that used by Lentz, one should check that source too. There are also some papyrus fragments not included in Lentz or on the TLG. ${ }^{55}$ The work is no. 13 in both the $T L G$ list and that of Schultz, and no. 7 in Dyck's list. For further information see Dyck. ${ }^{56}$

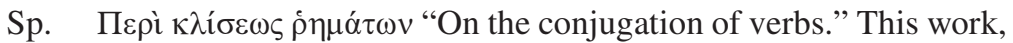
probably spurious, concerns difficult verb forms and is related to

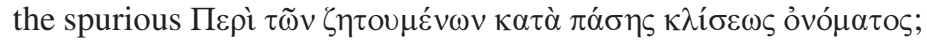
sometimes the two are joined together and known by the over-

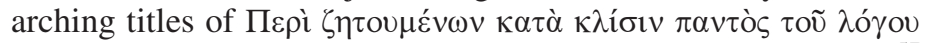

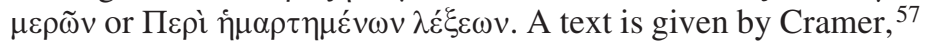
and the work is no. 45 in Schultz's list and no. 48 in the printed $T L G$ Canon; ${ }^{58}$ although this title is not listed in the online $T L G$ Canon it is effectively the second part of work no. 47 in the online $T L G$ numeration, and therefore the text is available online.

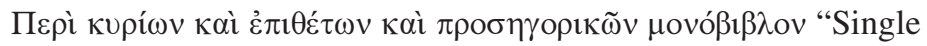
book on proper names and adjectives and common nouns." This work on the accentuation of proper names and how it differs from the accentuation of the same words when they are common nouns now survives only as a small collection of fragments; the only usable text is in Lentz's edition, ${ }^{59}$ though it is not very good. This work is no. 3 in the TLG list and no. 2 in Schultz's list.

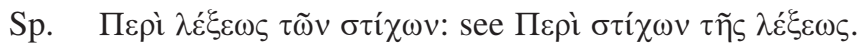

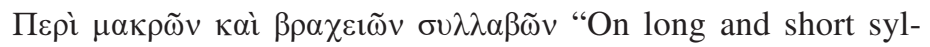
lables." La Roche and on his authority Lentz and Schultz state that a work with this title, attributed to Herodian, exists in a Vienna manuscript, Codex Vindob. Phil. gr. 172, fol. 216r-219r;

53. See Dyck 1993, 776-83.

54. Lentz 1867-70 in $G G$ 3.2: 634-777 + corrigenda 1260-61; cf. GG 3.1: cviii.

55. These can be found in Wouters 1973 and 1979, 231-36.

56. Dyck 1993, 789.

57. Cramer 1836, 256-62.

58. Berkowitz and Squitier 1990.

59. Lentz $1867-70$ in $G G 3.2$ : 1-6; cf. $G G 3.1$ : lxxi. 
they imply that it has never been edited. ${ }^{60}$ But, as observed by Hunger in his catalogue of Vienna manuscripts, ${ }^{61}$ the work to which this manuscript is a witness has indeed been published, by Hermann. ${ }^{62}$ La Roche's mistake is understandable, for Hermann's edition does not attach Herodian's name to the work

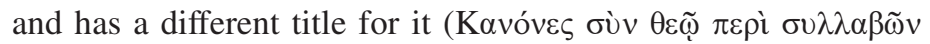

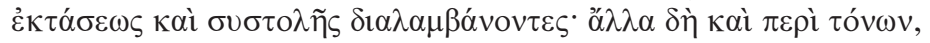

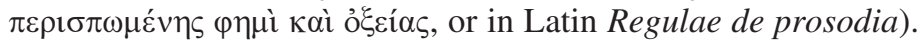
Moreover, the text in Hermann's edition differs from that in the manuscript in numerous places: sometimes Hermann prints substantial amounts of material that are absent from the manuscript, sometimes (especially toward the beginning, where Hermann's sources were lacunose) the manuscript contains material that is absent from Hermann, and sometimes the two simply differ-but there is enough overlap to make it clear that, fundamentally, they are the same text. In Hermann's edition this piece is only the first section of a long work; ${ }^{63}$ it is immediately followed, without any kind of break or new title, by the material that substantially

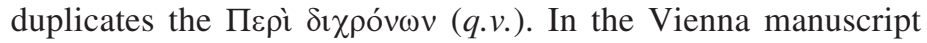

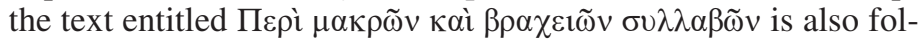

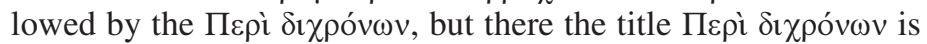

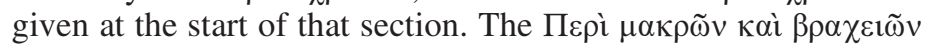
$\sigma \cup \lambda \lambda \alpha \beta \tilde{\omega} v$ is no. 51 in Schultz's list and does not appear in other lists.

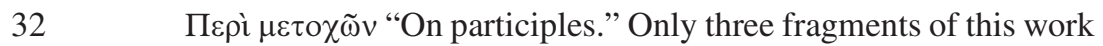
remain; they are given by Lentz. ${ }^{64}$ The work is no. 19 in the lists of both Schultz and the TLG.

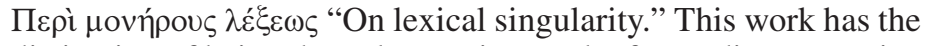
distinction of being the only genuine work of Herodian to survive intact. The text given in Lentz is a reprint of the one produced by Lehrs (with extensive commentary not reproduced by Lentz) and needs to be supplemented by the works of Egenolff; 65 the $T L G$ contains Lentz's/Lehrs' edition but not Egenolff's supplements. A new edition with extensive commentary has been prepared, though not yet published, by Aikaterini Papazeti. ${ }^{66}$ The work is no. 33 in the lists of Schultz and the TLG and no. 10 in Dyck's list; for further information see Dyck. ${ }^{67}$

60. La Roche 1866, 114; Lentz 1867-70 in GG 3.1: xvi; Schultz 1913, 973.

61. Hunger 1961, b276-78.

62. Hermann 1801, 422-32; I have verified Hunger's claim by checking a photograph of the manuscript.

63. Hermann 1801, 422-70.

64. Lentz $1867-70$ in $G G 3.2$ : 784-85; cf. $G G 3.1$ : cx.

65. Lentz 1867-70 in GG 3.2: 908-52 + corrigenda 1263; cf. GG 3.1: cxvii-cxxii; Lehrs 1848, 7-157; Egenolff 1884, 62-70; 1900, 254-55.

66. Papazeti 2008

67. Dyck 1993, 790-91. 


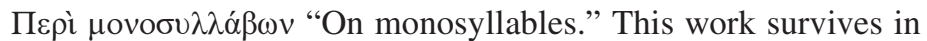
only two fragments, which are given by Lentz. ${ }^{68}$ The work is no. 28 in the lists of both Schultz and the TLG.

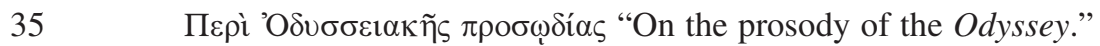
This work must have been a counterpart of the Пвpi 'I $\lambda_{1} \alpha \kappa \tilde{\eta} \varsigma$ $\pi \rho 0 \sigma \omega \delta$ ías, but less is known about it owing to the generally poorer preservation of ancient scholarship on the Odyssey. It concerned observations on accentuation, aspiration, and vowel length in the Odyssey and is lost apart from fragments in the scholia to the Odyssey. Lentz provides a text, though this needs to be supplemented by the additions and corrections offered by Ludwich partly in an appendix to Lentz's edition and partly in a separate work. ${ }^{69}$ Fragments for which the source text is a scholion from the beginning of the Odyssey can also be found in Filippomaria Pontani's new edition of the Odyssey scholia, ${ }^{70}$ and this text is preferable to that of Lentz/Ludwich. This work is no. 8 in the TLG list, no. $6 \mathrm{~b}$ in Schultz's, and no. 3 in Dyck's.

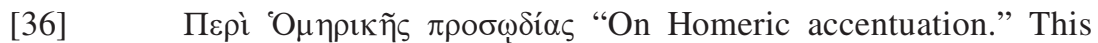
title is an overarching designation encompassing two works on

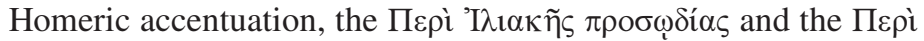

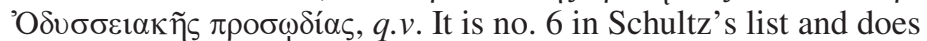
not appear in the others. Cf. Lentz's preface. ${ }^{71}$

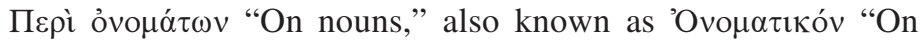

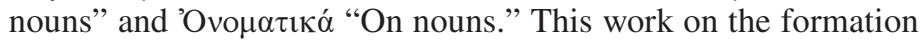
and accentuation of nouns and adjectives survives in fragments coming chiefly from the works of Choeroboscus. A text can be found in Lentz's edition, ${ }^{72}$ but as there is now a better edition of Choeroboscus than that used by Lentz (in $G G$ vol. 4 ), it is wise to check that source too. This work probably originally included the

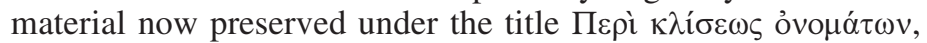
$q . v$. It is no. 12 in both the TLG list and that of Schultz.

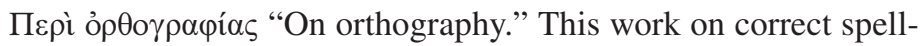
ing, though lost in its original form, survives in a very large body of fragments, most of which are edited by Lentz; ${ }^{73}$ there is controversy about the extent to which other material also belongs to this work. The work is generally believed to have included

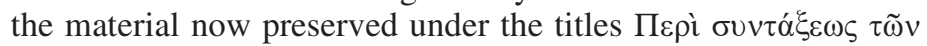

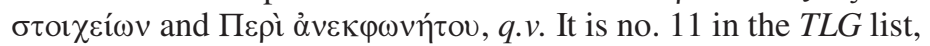

68. Lentz 1867-70 in GG 3.2: 903-4; cf. GG 3.1: cxv-cxvi.

69. Lentz 1867-70 in GG 3.2: 129-65; cf. GG 3.1: lxxxiii; Ludwich in GG 3.2: 1240-48; Ludwich 1891.

70. Pontani 2007-.

71. Lentz $1867-70$ in $G G 3.1$ : lxxiv.

72. Lentz 1867-70 in GG 3.2: 612-33 + corrigenda 1259-60; cf. GG 3.1: cv-cviii.

73. Lentz $1867-70$ in $G G 3.2$ : 407-611 + corrigenda 1255-59; cf. GG 3.1: xcviii-cv. 
no. 10 in Schultz's, and no. 6 in Dyck's. For further information see Dyck. ${ }^{74}$

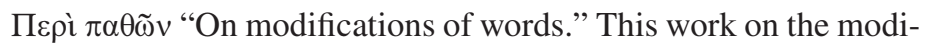
fications in spelling that connect one word or form to another related one survives as a very substantial collection of fragments, which can be found in Lentz's edition; ${ }^{75}$ an edition of new fragments from the Etymologicum genuinum exists in an unpublished dissertation by Nifadopoulos (2001, not available on the $T L G$ ). The work is no. 9 in the TLG list and no. 7 in Schultz's list; see also Dyck. ${ }^{76}$ Lentz's edition includes, separated from the main text by a horizontal line, extracts from the other works in the Herodianic corpus that pertain to $\pi \alpha \dot{\theta} \theta \eta$, keyed to the entries to which they most closely relate; ${ }^{77}$ the $T L G$ treats these as a separate work, listed as no. 34 and given the title "Пврі $\pi \alpha \theta \tilde{\omega} v$ (supplementum)." At the time of writing, the page numbers for this supplementum are very incorrect on the online version of the $T L G$ Canon, though they are correct in the printed version.

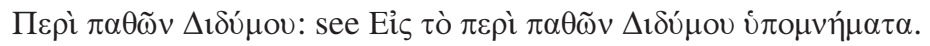

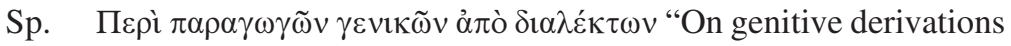
by dialect." This work, traditionally classified with the spuria, is a collection of queries about the declension of difficult words, with their answers; the title seems to come from the fact that the first few questions relate to genitives in non-Attic dialects, but the bulk of the work is not particularly concerned with either genitives or dialects. A text is given by Cramer, ${ }^{78}$ and the work is no. 45 in the TLG list and no. 39 in Schultz's list.

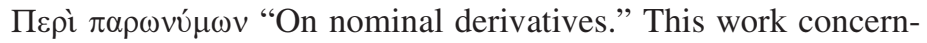
ing words derived from nouns survives as a substantial body of fragments, which are printed by Lentz. ${ }^{79}$ The work is no. 26 in the lists of both Schultz and the $T L G$.

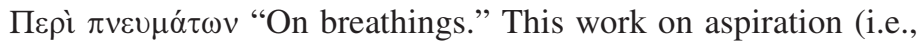
rough and smooth breathings) probably was originally part of

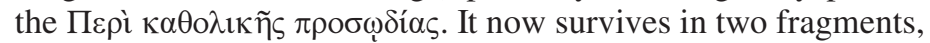
which are given by Lentz. ${ }^{80}$ The work is no. 5 in the TLG list and no. 4 in Schultz's list.

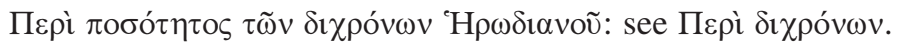

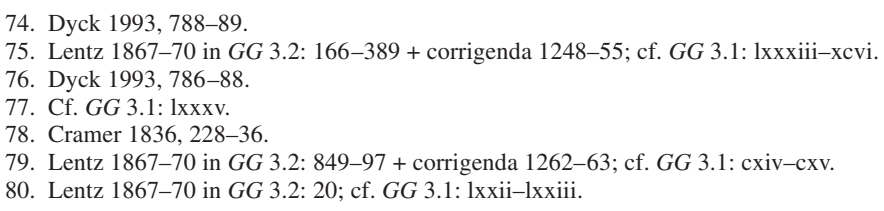




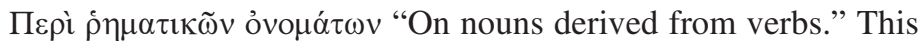
work concerning the derivation of nouns and adjectives from verbal stems survives in fragments, which are given by Lentz. ${ }^{81}$ The work is no. 27 in the lists of both Schultz and the TLG.

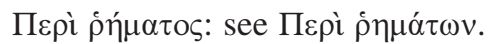

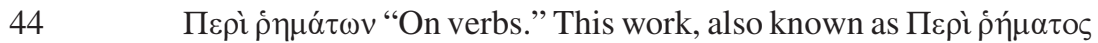
"On the verb," concerned the rules of conjugation. A substantial body of fragments survives and can be found in Lentz's edition. ${ }^{82}$ The work is no. 21 in the lists of both Schultz and the TLG.

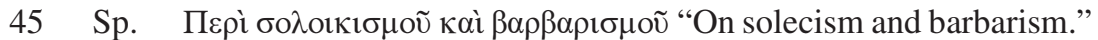

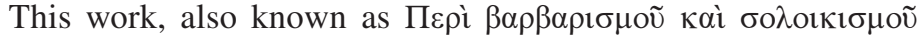
"On barbarism and solecism" and as De soloecismo et barbarismo "On solecism and barbarism," is traditionally classified with the spuria and concerns types of linguistic errors. There is a text by Nauck, ${ }^{83}$ and the work is no. 44 in the TLG list and no. 38 in Schultz's list.

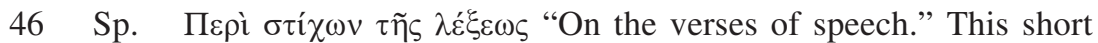

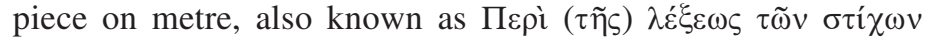
"On the verses of speech" and as De versibus "On verses," is probably not by Herodian. It has been published by Studemund, in an edition that supersedes one by De Furia bearing the title

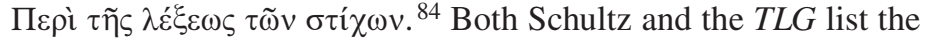

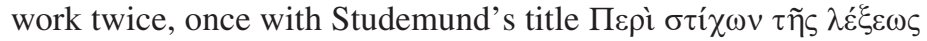
(no. 40 in the TLG list, no. 50 in Schultz's) and again with (a variant of) De Furia's title (no. 49 in the printed TLG Canon, work no. 49 but in 48th place in the online TLG list, and no. 47 in Schultz's), but comparison of the two texts makes it clear, as does Studemund's discussion, that they are the same work.

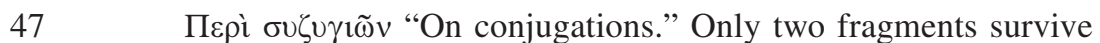
of this work; they can be found in Lentz's edition. ${ }^{85}$ It is no. 17 in both the $T L G$ list and that of Schultz.

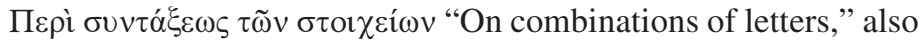

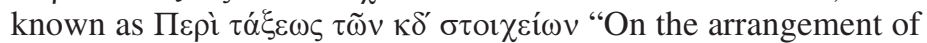
the 24 letters." This title is attached to a fairly substantial body of fragments concerning the properties of different letters/sounds in Greek. Lentz, treating it as a self-standing work, gives a text of the fragments, ${ }^{86}$ but it is likely that this material was originally

81. Lentz 1867-70 in $G G 3.2$ : 897-903; cf. GG 3.1: cxv.

82. Lentz $1867-70$ in $G G 3.2$ : $787-824$ + corrigenda 1262 ; cf. $G G 3.1$ : cx-cxii.

83. Nauck 1867, 294-312.

84. Studemund 1867, 618-19; De Furia 1814, 88

85. Lentz 1867-70 in $G G 3.2: 779$; cf. $G G$ 3.1: cx.

86. Lentz 1867-70 in GG 3.2: 390-406 + corrigenda 1255; cf. GG 3.1: xcvi-xcviii. 


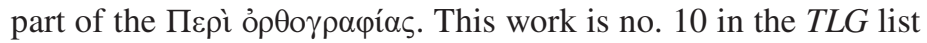
and no. 9 in Schultz's list.

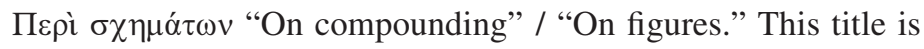
applied to two completely different things. The $T L G$ lists the first as no. 25 and the second as no. 35 ; Schultz lists the first as no. 25 and the second as no. 52 .

49 The first is a small set of fragments concerning compound words $(\sigma \chi \tilde{\eta} \mu \alpha$ in the sense of "compositional status"); these probably go back to genuine work of Herodian and are given by Lentz. ${ }^{87}$

Sp. The second is a composite rhetorical work that survives in considerable bulk ( $\sigma \chi \tilde{\eta} \mu \alpha$ in the sense of "rhetorical figure"); this probably has no connection with Herodian's own work but could go back to the second century C.E. The best edition of this rhetorical work is that of Kerstin Hajdú; 88 this is not available via the $T L G$, which uses instead a problematic and outdated edition.

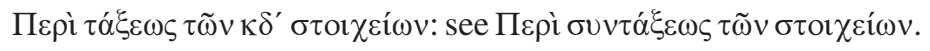

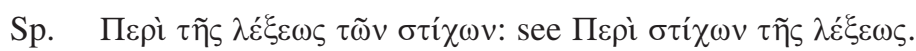

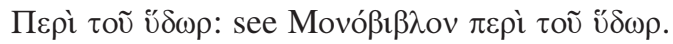

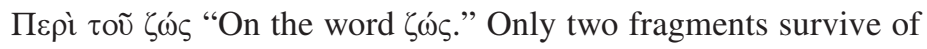
this work, which presumably discussed the inflectional peculiarities of the word $\zeta \omega \dot{\omega} \zeta$. The fragments can be found in Lentz, ${ }^{89}$ and the work is no. 16 in both the TLG list and that of Schultz.

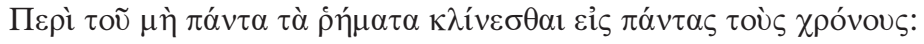

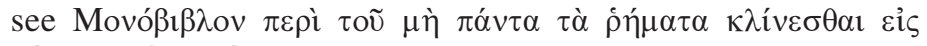

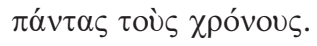

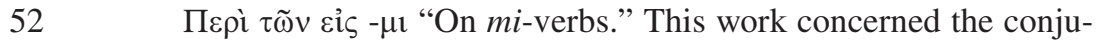
gation of verbs in $-\mu \mathrm{r}$ and now survives in a substantial body of fragments, which are printed by Lentz. ${ }^{90}$ The work is no. 22 in the lists of both Schultz and the $T L G$.

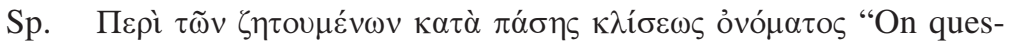
tions about every declension of the noun." This spurious work concerns declension and spelling; sometimes it is joined to the

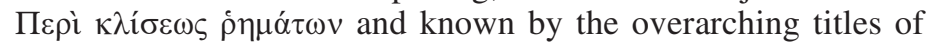

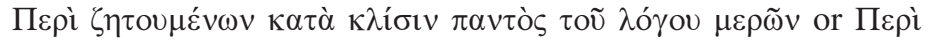

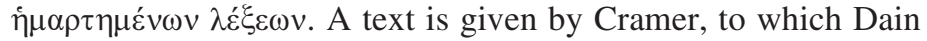
has added a short additional part from a different manuscript. ${ }^{91}$

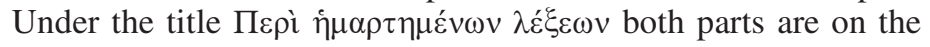

87. Lentz $1867-70$ in $G G 3.2$ : 847-49; cf. $G G 3.1$ : cxiii-cxiv.

88. Hajdú 1998.

89. Lentz 1867-70 in $G G$ 3.2: 778 ; cf. $G G$ 3.1: cix.

90. Lentz 1867-70 in $G G$ 3.2: 825-44 + corrigenda 1262; cf. $G G$ 3.1: cxii-cxiii.

91. Cramer 1836, 246-55; Dain 1954, 73-74. 
$T L G$, which gives Dain's portion the number 38 and Cramer's

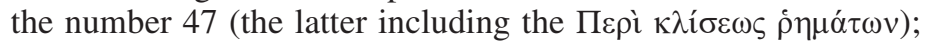
Schultz (who was unaware of Dain's portion) gives this work the number 44.

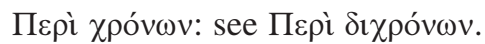

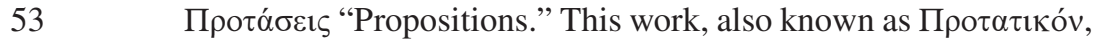
now survives in two short fragments. From these it is difficult to ascertain its topic, but it is thought to have concerned questions and answers about problems of grammar, spelling, and accentuation. The fragments are given by Lentz, ${ }^{92}$ and the work is no. 31 in the lists of Schultz and the TLG.

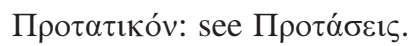

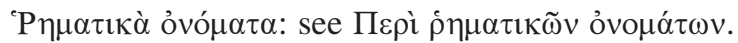

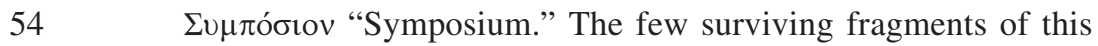
work suggest that it was concerned with etymology; Reitzenstein argued that it was a source for Athenaeus and was originally Atticist in orientation. ${ }^{93}$ The fragments are given by Lentz. ${ }^{94}$ The work is no. 30 in the lists of Schultz and the $T L G$, and no. 9 in Dyck's list.

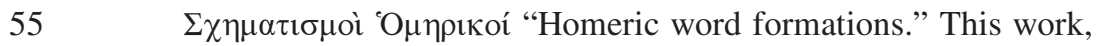
also known as Schematismi Homerici, is a glossary with etymological and inflectional information; it was not edited by Lentz but may nevertheless be genuine. A transcript of one manuscript has been produced by Egenolff, ${ }^{95}$ and the work is no. 41 in the $T L G$ list, no. 53 in Schultz's, and no. 13 in Dyck's; for further information see Dyck. ${ }^{96}$

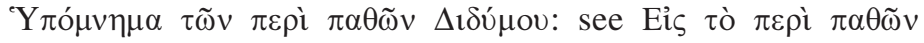

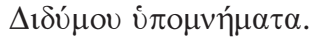

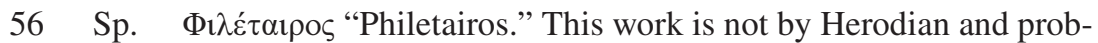
ably has no connection with him, though it was most likely written between the second and fourth centuries C.E. and therefore could date to his time. It is an Atticist glossary of considerable size; an edition is provided by Dain. ${ }^{97}$ The work is no. 37 in the TLG list, no. 54 in Schultz's list, and no. 12 in Dyck's. For important further information see Dyck. ${ }^{98}$

92. Lentz 1867-70 in $G G$ 3.2: 907 ; cf. $G G$ 3.1: cxvi.

93. Reitzenstein 1897, 371-97.

94. Lentz 1867-70 in GG 3.2: 904-6 + addendum 1263

95. Egenolff 1894.

96. Dyck 1993, 792

97. Dain 1954.

98. Dyck 1993, 791-92. 


\title{
Latin Titles
}

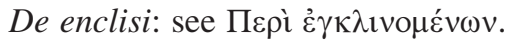

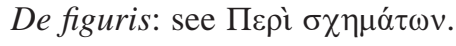

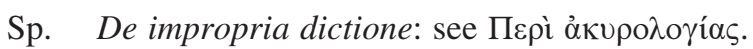

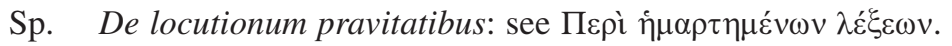

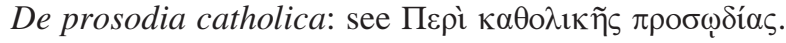

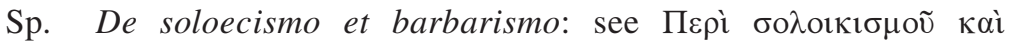
$\beta \alpha \rho \beta \alpha \rho \imath \sigma \mu о \tilde{v}$.

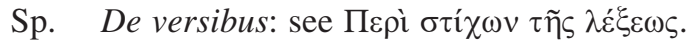

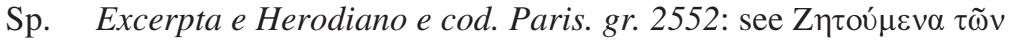

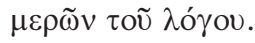

57 Sp. Excerpta e Herodiano "Excerpts from Herodian." This collection of spuria, also known as Fragmenta "Fragments," is given by Dain. ${ }^{99}$ It is no. 39 in the $T L G$ list and does not appear in other lists.

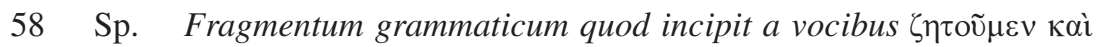

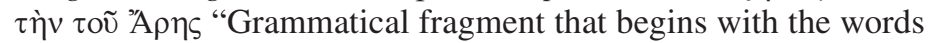

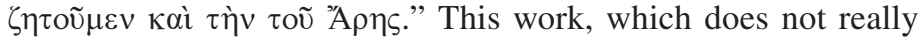
have a title and is assigned this one by the $T L G$ for convenience of identification, is a spurious treatise on declension and spelling. A text is given by Cramer, ${ }^{100}$ and the work is no. 54 (but in 50th place) in the online $T L G$ list; it is not included in other lists.

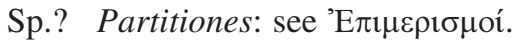

Philetaerus: see $\Phi \mathbf{\imath} \hat{\varepsilon} \tau \alpha \iota \rho о \varsigma$.

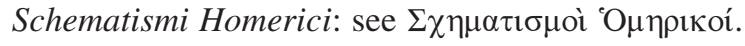

University of Reading

\author{
APPEndix: An AdDitional Portion

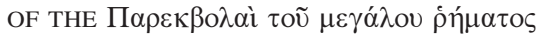

In 1897 Reitzenstein pointed out that La Roche's text of the П $\alpha \rho \varepsilon \kappa \beta о \lambda \alpha i ̀ ~ \tau o \tilde{v ~} \mu \varepsilon \gamma \alpha \dot{\alpha} \lambda o v$

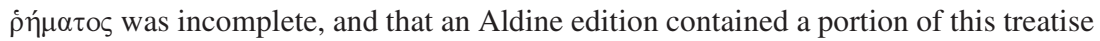
not printed by anyone else. ${ }^{101}$ Unfortunately, however, Reitzenstein made a mistake in his description of the location of the extra material relative to that printed by La

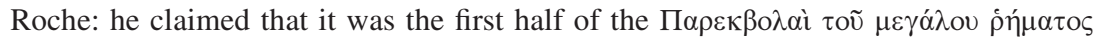

99. Dain $1954,75-82$.

100. Cramer 1836, 237-45.

101. Reitzenstein 1897, 364; cf. La Roche 1863 and Manutius 1496. 
that appeared only in the Aldine, whereas in fact it is the last few pages. This mistake, together with a certain unclarity in Reitzenstein's discussion, resulted in Schultz stating that the Aldine contained an entire otherwise unknown work, the Ađopíal кai

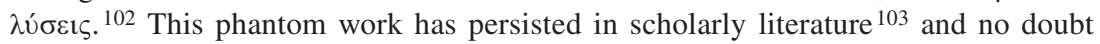
caused frustration to many generations of readers.

Despite Reitzenstein's claims that the extra material was "unknown," it had not

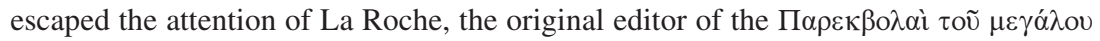
¡́ $\mu \alpha \tau$ cs. La Roche used four manuscripts for his edition, and one of them in fact contained the material in the Aldine; La Roche refrained from including it in his edition on the grounds that he did not think it had originally belonged to this work. ${ }^{104}$ The manuscript in which La Roche found the material, Vienna's Codex Vindob. Phil. gr. 271, dates to the sixteenth century 105 and therefore cannot be the source of the Aldine; it is probably a copy of the printed book. The Aldine therefore remains the best source for the additional material.

La Roche is, in my opinion, correct that this material is a later addition to the treatise - but it is not without intrinsic interest. I therefore present here a transcript of this extra material as given by the Aldine, ${ }^{106}$ for the convenience of those who do not have access to it; a proper re-edition would be highly desirable, but this is not the place to

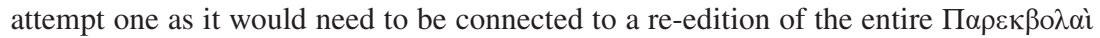

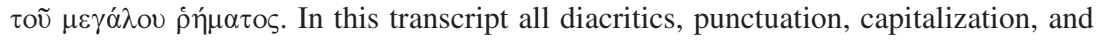
paragraphing follow the Aldine.

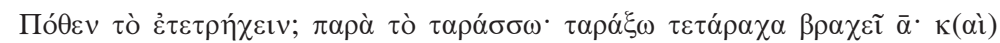

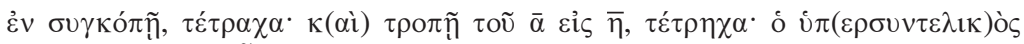

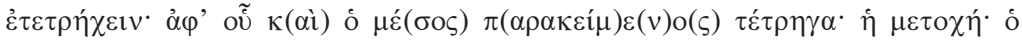
$\tau \varepsilon \tau \rho \eta \gamma \omega ́ s$.

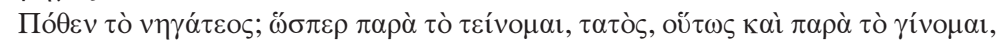

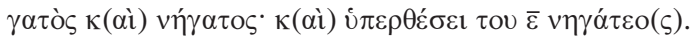

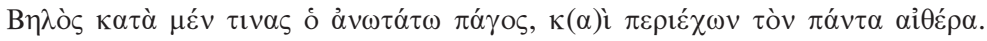

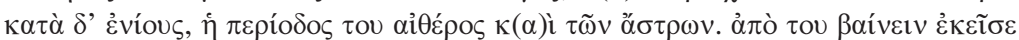

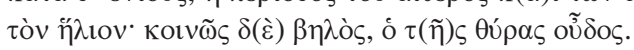

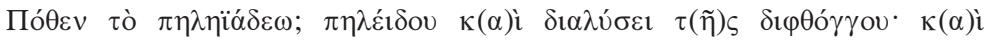

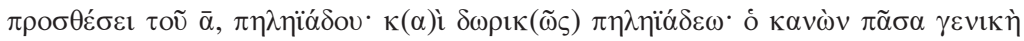

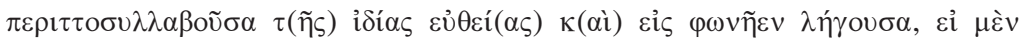

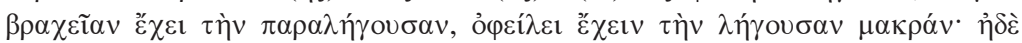

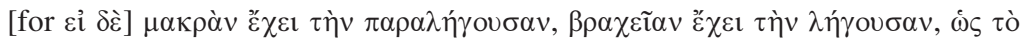

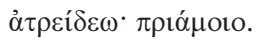

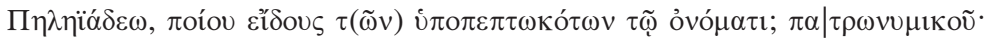

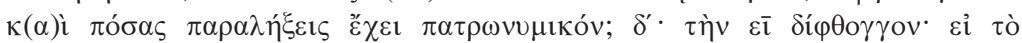

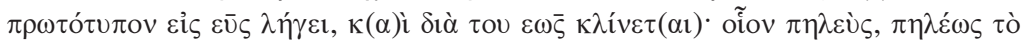

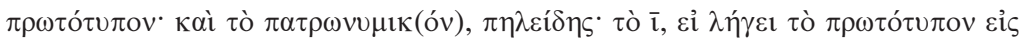

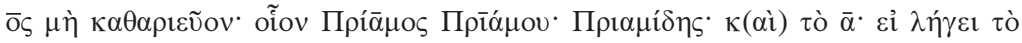

102. Schultz 1913,972

103. Cf. Berkowitz and Squitier 1990, 197.

104. La Roche 1863, 37.

105. Hunger 1961, b375.

106. Manutius 1496 , folio $214 \mathrm{ab}$. 


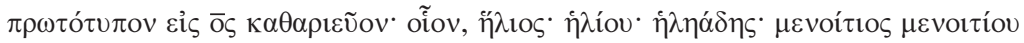

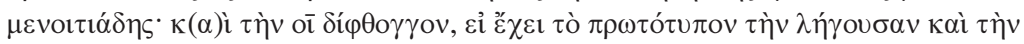

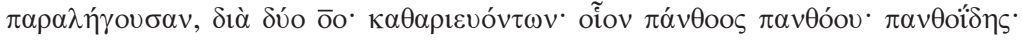

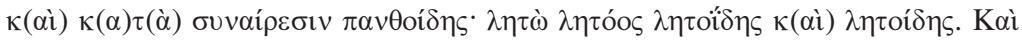
$\tau \grave{\alpha}$ ö $\mu \mathrm{ot \alpha}$.

\section{$\mathrm{TE} \Lambda \mathrm{O} \Sigma$}

\section{LITERATURE CITED}

Bekker, Immanuel. 1821. Anecdota Graeca III. Berlin.

Berkowitz, Luci, and Karl A. Squitier. 1990. Thesaurus Linguae Graecae: Canon of Greek Authors and Works ${ }^{3}$. Oxford.

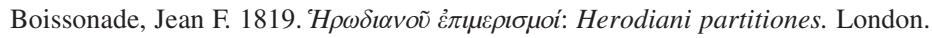

Cohn, Leopold. 1888. Unedirte Fragmente aus der atticistischen Litteratur. Rheinisches Museum NF 43: 405-18.

Cramer, John A. 1836. Anecdota Graeca e codd. manuscriptis bibliothecarum Oxoniensium III. Oxford.

Dain, Alphonse. 1954. Le "Philétaeros" attribué à Hérodien. Paris.

De Furia, Franciscus. 1814. Appendix ad Draconem Stratonicensem, complectens Trichae, Eliae Monachi, et Herodiani Tractatus de Metris. Leipzig. [This is an appendix to Hermann 1812 but does not appear in early printings of that work.]

Dickey, Eleanor. 2007. Ancient Greek Scholarship. New York.

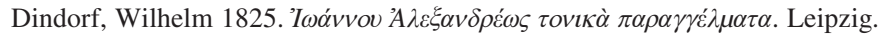

Dyck, Andrew R. 1981. Notes on the Epimerismoi Attributed to Herodian. Hermes 109: 225-35. . 1993. Aelius Herodian: Recent Studies and Prospects for Future Research. Aufstieg und Niedergang der römischen Welt II 34.1: 772-94. . 1995. Epimerismi Homerici. Vol. 2. Berlin.

Egenolff, Peter. 1884. Bericht über die griechischen Grammatiker. Jahresbericht über die Fortschritte der classischen Alterthumswissenschaft, begründet von Conrad Bursian 38: 43-98.

. 1894. Zu Herodianos technikos. Neue Jahrbücher für Philologie und Paedagogik (= Jahrbücher für classische Philologie) 149: 337-45.

. 1900. Zu Lentz' Herodian I. Philologus 59: 238-55.

1902. Zu Lentz' Herodian II. Philologus 61: 77-132 and 540-76.

. 1903. Zu Lentz' Herodian III. Philologus 62: 39-63.

Erbse, Hartmut. 1960. Beiträge zur Überlieferung der Iliasscholien (Zetemata 24). Munich. . 1969-88. Scholia Graeca in Homeri Iliadem (scholia vetera). Berlin.

$G G=$ Grammatici Graeci (Leipzig 1867-1910, repr. Hildesheim 1965). The Herodian sections of this work are unaltered reprints of Lentz 1867-70. Arthur Ludwich has provided a set of addenda and corrigenda to vols. 3.1 and 3.2, which are printed at the end of vol. 3.2 (pp. 1233-64).

Hajdú, Kerstin. 1998. Ps.-Herodian, De Figuris. Berlin.

Hermann, Gottfried. 1801. De emendanda ratione Graecae grammaticae. Leipzig. 1812. Draconis Stratonicensis Liber de Metris Poeticis, Ioannis Tzetzae exegesis in Homeri Iliadem. Leipzig.

Hunger, Herbert. 1961. Katalog der griechischen Handschriften der Österreichischen Nationalbibliothek 1: Codices historici, codices philosophici et philologici. Vienna. [Available online at http://www.manuscripta-mediaevalia.de/hs/kataloge/HSK0781.htm.]

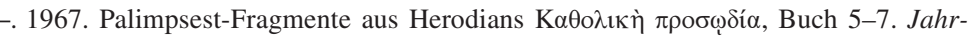
buch der Österreichischen byzantinischen Gesellschaft 16: 1-33. 


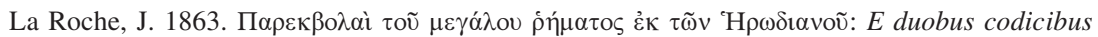
Caes. Reg. biblioth. Vindobonensis (Jahresbericht über das k. k. akademische Gymnasium in Wien für das Schuljahr 1862-3). Vienna.

1866. Die Homerische Textkritik im Alterthum. Leipzig.

Lehrs, Karl. 1848. Herodiani scripta tria emendatiora. Königsberg (2nd ed. Berlin 1857).

Lentz, August. 1867-70. Herodiani Technici reliquiae. Leipzig (repr. as GG vol. 3).

Ludwich, Arthur. 1891. Herodiani Technici Reliquiarum Supplementum. Königsberg. . 1905. Anekdota zur griechischen Orthographie (Verzeichnis der auf der Königlichen Albertus-Universität zu Königsberg im Winter-Halbjahre vom 16. Oktober 1905 an zu haltenden Vorlesungen und der öffentlichen akademischen Anstalten). Königsberg.

Manutius, Aldus. 1496. Thesaurus: Cornucopiae et horti Adonidis. Venice.

Nauck, August. 1867. Lexicon Vindobonense. St. Petersburg (repr. Hildesheim 1965).

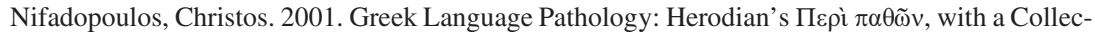
tion of New Fragments from Etymologicum Genuinum. Ph.D. diss., University of Cambridge.

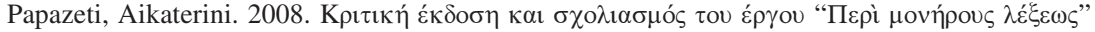

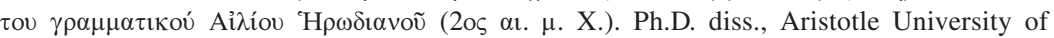
Thessaloniki.

Pierson, Joannes, and Georg A. Koch. 1830. Moeridis Atticistae lexicon Atticum, accedit Aelii Herodiani Philetaerus. Leipzig.

Pontani, Filippomaria. 2007-. Scholia Graeca in Odysseam. Rome.

Reitzenstein, Richard. 1897. Geschichte der griechischen Etymologika. Leipzig (repr. Amsterdam 1964).

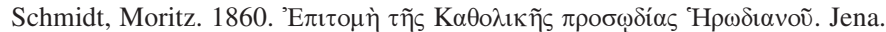

Schultz, Hermann. 1913. Herodianos 4. RE 8: 959-73.

Stephanus, Henricus [= Estienne, Henri]. 1865. Thesaurus Graecae Linguae. Rev. ed. Vol. 8. Paris.

Studemund, W. 1867. Der pseudo-Herodianische Tractat über die e`̊ $\eta$ des Hexameters. Neue Jahrbücher für Philologie und Paedagogik (= Jahrbücher für classische Philologie) 95: 609-23.

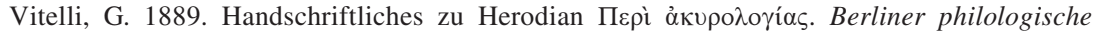
Wochenschrift 29/30 (Jahrgang 9): 907.

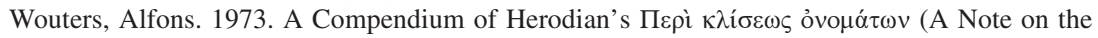
New Grammatical Papyrus in Florence). ZPE 11: 242-44. 1979. The Grammatical Papyri from Graeco-Roman Egypt. Brussels.

Xenis, George. 2014. Iohannis Alexandrini Praecepta Tonica. Berlin. 